\title{
Medical Versus Surgical Treatment of Incomplete First Trimestric Abortion
}

\author{
Aseel Mosa Jabber_aseel-m@utq.edu.iq \\ College of Medicine / Thi-qar University
}

\begin{abstract}
Objective: to assess efficacy and risks of medical treatment of incomplete abortion using misoprostol versus surgical procedures.

Methods: A prospective comparative study included 208 women with incomplete abortion with gestational age between $5^{\text {th }}$ and $12^{\text {th }}$ week randomized equally to two groups Group I received 600 micro gram misoprostol as single oral dose and Group II underwent surgical dilatation and evacuation. Primary outcome was successful treatment all women give a written acceptance of being involved in the trial.

Results: There was no statistically significant difference between Misoprostol and surgical groups regarding endometrial thickness evaluated after treatment $(10.5 \pm 2.65$ versus. $9.3 \pm 1.97$ respectively, where $P$ value 0.251 Non significant, treatment failure (11 versus. 6 respectively, where $P$ value 0.071 Non significant), those with blood loss more than 500 cc ( 1 versus. 3 respectively, where P value 0.482 Non significant ) and those who needed recurrettage ((11 versus. 6 respectively, where value 0.064 Non significant). Side effects of treatment showed no statistically significant difference between the studied women (fever occurred in 3 versus. 1, IUS in 0 versus. 1 and vomiting occurred in 1 versus. 3 in medical versus. surgical women respectively, where $\mathrm{P}$ value $>0.05$ ) except diarrhea which was much more common in women under Misoprostol treatment (28 versus. 0 respectively, where value $<\quad 0.001)$.
\end{abstract} Conclusion: Medical treatment is effective and acceptable and less costly than surgical treatment in women with incomplete abortion.

\section{Keyward : Pregnancy. Misoprostol . Abortion in Nassiriyah}

\section{Introduction}

Abortion derives from the Latin aboriri-to miscarry. Definition of abortion( Miscarriage) is the spontaneous or induced termination of pregnancy before viability of the fetus [1].
Miscarriage is the most common complication of early pregnancy, and remains an important clinical problem. Approximately 20\% of women attending early pregnancy department suffer a miscarriage [2]. Nearly $50 \%$ of pregnancies 
are lost in the early stages and $15 \%$ of fertilized oocytes will fail to implant [3] beside the loss of $20-25 \%$ of pregnancies without clinical prediction. [4]. These percentages suggest abortion rate of $12-19 \%$ being detected clinically [5]. Bleeding that follows partial or complete placental separation and dilation of the cervical os is termed incomplete abortion. Prior to $10^{\text {th }}$ week of pregnancy duration,the fetus and the placenta are frequently expelled together, but later, they deliver separately [1].

Unless there is serious bleeding or infection with an incomplete abortion, any of three options are reasonableexpectant, medical, or surgical management. Each has its own risks and benefits-for example, the first two are associated with unpredictable bleeding, and some women will undergo unscheduled curettage. Expectant management of spontaneous incomplete abortion has failure rates as high as 50 percent. Medical therapy has varying failure rates of 5 to 40 percent. In 1100 women with suspected first-trimester abortion, 81 percent had a spontaneous resolution [6]. Curettage usually results in a quick resolution that is 95- to 100percent successful. It is invasive and not necessary for all women.

It is possible that patients and clinicians option for surgical methods when there is not a strict protocol for medical treatment [7]. Several randomized studies that compared these management schemes were reviewed by Neilson (2010)[8]. Studies that included women with vaginal bleeding reported greater success for medical therapy than did studies that excluded such women [9]. Importantly, Smith and coworkers (2009) reported that subsequent pregnancy rates did not differ among these management methods [10].

Misoprostol was administered to treat gastric ulcer in those who use certain analgesics.At the present time, it is used more often to enhance uterine contractility. Nowadays, clinicians prescribe it for aborting women instead of surgical intervention [11]. The medical treatment of abortion, that is almost $95 \%$ successful to expel all products of conception completely in the early stages of pregnancy, has been developed as a realistic alternative to surgical evacuation [12]. The method involves the combinations of mifepristone, antagonist of progesterone, and misoprostol, with chemical similarity to prostaglandin E1 shows a cheaper alternative to surgery [13]. This study was done to assess risks and benefits of medical treatment of incomplete abortion with misoprostol versus surgical procedures.

\section{Patients and Methods}

This prospective comparative study included 208 women who attended the outpatient clinic and casualty at Al- 


\section{Email:utjmed@utq.edu.iq}

Habobi Teaching Hospital in Thi qar province/Iraq, between March 2015 and August 2016. Ethical approval was obtained from the regional committee and all women give a written acceptance of being involved in the trial.

The 208 women included in the present study confirmed to be pregnant and presenting with spontaneous first trimestric miscarriage complaining of mild or moderate vaginal bleeding with Gestational age between $5^{\text {th }}$ and $12^{\text {th }}$ week calculated based on the date of the last menses and confirmed by ultrasound examination. Women with severe vaginal bleeding , haemodynamic unstable, missed or complete abortion, ectopic pregnancy or gestational trophoblastic disease were excluded from the study. Patients with signs of sepsis and those with contraindication to misorpostol or prostaglandins were also excluded from the study.

All participants were subjected to full history taking including age, LMP for confirmation of gestational age, medical disorders and history of previous abortions, general, abdominal and local examinations. PV and bimanual examination to detect size of uterus, its position, mobility and any cervical mass or adnexal masses.

Transvaginal ultrasound was done to all participants using $5 \mathrm{MHZ}$ transvaginal probe to assess uterine

\section{Web Site: https://imed.utq.edu.iq}

size, endometrial thickness, uterine cavity and presence of remnants. Automated web-based randomization system was used to distribute the women equally into one of the study groups. Group I (104 patients) medically treated as outpatient received $600 \mu \mathrm{g}$ misoprostol (misotac ()) as single oral dose [14]. Group II included 104 patients underwent surgical dilatation and evacuation. All patients were asked to return immediately if severe vaginal bleeding occurs, otherwise to check after one week for follow up with transvaginal U/S. Treatment was considered successful if no vaginal bleeding and TVS showed clear endometrial line with thickness equal to or less than 12 $\mathrm{mm}$ [12]. Primary outcome was successful treatment. Secondary outcomes included were side effects and patients satisfaction.

Describing data was done through mean \pm standard deviation ( \pm SD), and range, or frequencies and percentages as needed. $t$ test was used to compare the different methods of estimating gestational age was done. Accuracy of different estimation parameters in relation to the LMP parameter was done within 1 week error. Statistical significance was confirmed at $p$ values less than 0.05 . SPSS 15 program was used for statistical analysis (Statistical Package for the Social Science; SPSS Inc., Chicago, IL, USA) for Microsoft Windows

(2006). 


\section{Results}

No significant difference was found between the two groups considering age, parity, BMI and gestational age, the presence of medical disorders as hypertension and Diabetes mellitus showed no statistical difference when comparing women in the two groups, Examination of women showed no variations when comparing the 2 groups in their relations with vital signs, vaginal bleeding quantity, the existance of lower abdominal pain or endometrial thickness evaluated by TVS as shown in (Table 1).

Table (1): Baseline characteristics of the study population

\begin{tabular}{|c|c|c|c|c|}
\hline & & $\begin{array}{l}\text { Misoprostol group } \\
(\mathbf{n}=\mathbf{1 0 4})\end{array}$ & $\begin{array}{l}\text { Surgical } \\
\text { evacuation } \\
\text { group }(n=104)\end{array}$ & $P$ value \\
\hline \multicolumn{2}{|c|}{ Age (years) } & $27.41 \pm 5.32$ & $26.82 \pm 5.98$ & $\begin{array}{l}0.56 \\
1 \mathrm{NS}\end{array}$ \\
\hline \multicolumn{2}{|l|}{ Parity } & $2.62 \pm 1.28$ & $2.9 \pm 1.31$ & $\begin{array}{l}0.51 \\
3 \mathrm{NS}\end{array}$ \\
\hline \multicolumn{2}{|c|}{ BMI (Kg/m2) } & $27.9 \pm 3.63$ & $28.71 \pm 3.78$ & $\begin{array}{l}0.49 \\
2 \mathrm{NS}\end{array}$ \\
\hline \multicolumn{2}{|c|}{ GA (weeks) } & $9.87 \pm 1.65$ & $8.9 \pm 1.86$ & $\begin{array}{l}0.37 \\
1 \mathrm{NS}\end{array}$ \\
\hline \multirow[t]{4}{*}{$\begin{array}{l}\text { Vital } \\
\text { signs }\end{array}$} & SBP & $124.2 \pm 5.58$ & $118.7 \pm 6.79$ & $\begin{array}{l}0.35 \\
4 \mathrm{NS}\end{array}$ \\
\hline & DBP & $76.7 \pm 4.91$ & $73.8 \pm 4.86$ & $\begin{array}{l}0.12 \\
7 \mathrm{NS}\end{array}$ \\
\hline & HR & $81 \pm 3.58$ & $82.5 \pm 4.04$ & $\begin{array}{l}0.11 \\
\mathrm{NS}\end{array}$ \\
\hline & Temperature & $37.1 \pm 0.08$ & $36.9 \pm 0.08$ & $\begin{array}{l}0.87 \\
5 \mathrm{NS}\end{array}$ \\
\hline \multirow{3}{*}{$\begin{array}{l}\text { Medical } \\
\text { disorders* }\end{array}$} & None & 92 & 93 & \multirow{3}{*}{$\begin{array}{l}0.89 \\
8 \mathrm{NS}\end{array}$} \\
\hline & Hypertension & 8 & 7 & \\
\hline & $\begin{array}{l}\text { Diabetes } \\
\text { mellitus }\end{array}$ & 4 & 4 & \\
\hline \multirow[t]{2}{*}{ Bleeding* } & Mild & 74 & 69 & \multirow{2}{*}{$\begin{array}{l}0.75 \\
2 \mathrm{NS}\end{array}$} \\
\hline & Moderate & 30 & 35 & \\
\hline \multirow{2}{*}{$\begin{array}{l}\text { Lower } \\
\text { abdominal } \\
\text { Pain* }\end{array}$} & Yes & 83 & 79 & \multirow{2}{*}{$\begin{array}{l}0.67 \\
7 \mathrm{NS}\end{array}$} \\
\hline & No & 21 & 25 & \\
\hline \multicolumn{2}{|c|}{ Endometrial thickness } & $20.8 \pm 3.58$ & $21.3 \pm 2.91$ & $\begin{array}{l}0.78 \\
3 \mathrm{NS}\end{array}$ \\
\hline
\end{tabular}


Data presented as mean \pm standard deviation.

* Data are presented as number percent.

BMI Body mass index; GA Gestational age ; SBP Systolic blood pressure ; DBP Diastolic blood pressure ; HR Heart rate; NS non significant.

No statistically significant difference was found between the two groups regarding endometrial thickness evaluated after treatment, treatment failure, those with blood loss more than $500 \mathrm{cc}$ and those who needed recurrettage, the side effects of treatment showed no significant difference between women in different groups apart from diarrhea that occurred more commonly in women under Misoprostol treatment (Table 2).

Table (2): Outcome parameters among the study groups.

\begin{tabular}{|c|c|c|c|c|}
\hline & & $\begin{array}{l}\text { Misoprostol } \\
\operatorname{group}(n=104)\end{array}$ & $\begin{array}{l}\text { Surgical } \\
\text { evacuation } \\
\operatorname{group}(n=10)\end{array}$ & P value \\
\hline Failure & & 11 & 6 & $0.071 \mathrm{NS}$ \\
\hline Endometrial th & ness* & $10.5 \pm 2.65$ & $9.3 \pm 1.97$ & $0.251 \mathrm{NS}$ \\
\hline Bleeding $>500 \mathrm{c}$ & & 1 & 3 & $0.482 \mathrm{NS}$ \\
\hline Complications & Fever & 3 & 1 & $0.652 \mathrm{NS}$ \\
\hline & IUS & 0 & 1 & $0.784 \mathrm{NS}$ \\
\hline & Diarrhea & 28 & 0 & $\begin{array}{l}<0.001 \\
\mathrm{HS}\end{array}$ \\
\hline & Vomiting & 1 & 3 & $0.584 \mathrm{NS}$ \\
\hline Need for recure & & 11 & 6 & $0.064 \mathrm{NS}$ \\
\hline Have no compli & ion & 49 & 84 & \\
\hline
\end{tabular}

Data are presented as number percent.

* Data presented as mean \pm standard deviation.

IUS Intrauterine synechia; NS Non significant; HS Highly significant.

spontaneous are one of the main reasons of maternal hazards [17]. One

\section{Discussion}

Early pregnancy failure is a common occurrence, affecting one-third of early pregnancies and one-fourth of all women [16]. Complications associated with abortion whether induced or

of the usual hazards of early pregnancy is abortion. It has risks whether medically or psychologically. [18]. Our study confirmed that 


\section{Email:utjmed@utq.edu.iq}

medical treatment of incomplete abortion is equally effective as surgical treatment with comparable side effects. That was clear as failure of medical treatment occurred in 11 women while it occurs in 6 women who underwent surgical treatment and women with successful treatment had closely similar endometrial thickness evaluated after treatment. Also complications of treatment as fever, development of intrauterine synechia (only 1 case after surgical treatment came 3 months after evacuation complaining of hypomenorrhea and hysteroscopic evaluation revealed mild intrauterine adhesions) and vomiting were comparable among the two study groups. These finding can be explained by the ability of Misoprostol to induce effective uterine contraction at any gestational age. Zhang and colleagues (2005) demonstrated that misoprostol is an acceptable alternative to vacuum aspiration for failure of the early pregnancy treatment with success rate of medical management was $84 \%$ compared to the $97 \%$ success of surgical management [19]. Behnamfar and colleagues (2013) study included 133 women with missed abortion of smaller than 12 weeks gestational age, they was given $800 \mathrm{mcg}$ of vaginal misoprostol with reported rate of success of $92.4 \%$ [20]. In a systematic review, Neilson and colleagues (2010) assessed cases with incomplete abortion regarding success, reliability of the medical treatment and stated

\section{Web Site: https://imed.utq.edu.iq}

that misoprostol and expectant treatments are good replacement of the surgical management. In a more recent systematic review, the same authors analyzed 12 studies comparing misoprostol with surgical evacuation and reported a lower rate of success with misoprostol to achieve complete uterine evacuation than surgery but high rate of success for either misoprostol or surgery methods [21]. In a randomized controlled trial, to evaluate the results of medical treatment of missed miscarriage in 241 women at gestational ages smaller than 13 weeks' gestation, failure of medical treatment was reported in $13.3 \%$ and complete evacuation was achieved in $78.0 \%$ of them [22]. The main strength in our study is the absence of dropout cases and availability of most data needed for analysis. Medical treatment is a good alternative and cheaper to surgical one. It is less costly than surgical treatment [23]. It can be used as an outpatient and inexpensive treatment option, which is available on demand and easy to use [24]. A non surgically skilled physician can prescribe the medical treatment making it easier to access these patients, lowering hospital financial costs and saving more skilled health care providers time [25,26]. Surgical interventions need a skilled surgeon and equipped centers [27]. This seems even more important in view of the long-term consequences of curettage, which were beyond the scope of our present study. An earlier 
meta-analysis showed that $19 \%$ of women develop intrauterine adhesions (Asherman syndrome) after undergoing curettage, which might impair future fertility in particular in case of dense adhesions [28]. Another recently performed metaanalysis demonstrated an increased risk of preterm birth in subsequent pregnancies of women with a history of curettage (OR 1.3, 95\% CI 1.2-1.4). The subsequent risk of very preterm birth <28 weeks is increased even more (OR 1.7, 95\% CI 1.5-1.9) and of concern in view of the frequent use of curettage in daily practice [29]. For every four women who were managed expectantly in our study, 3 of them were able to avoid undergoing a surgical procedure, while in 2 out of 30 women treated with curettage, a second intervention was performed. Furthermore, since histopathology only confirmed the presence of pregnancy tissue in one third of samples, it is likely that the proportion of women with successful expectant management is higher than currently reported [30]. We concluded that medical treatment is effective and acceptable and less costly than surgical treatment in women with incomplete abortion.

\section{References}

[1]Cunningham FG, Leveno KJ, Bloom SL, Hauth JC, Rouse DJ and Sponge CY. Abortion . In: Cunningham FG, Williams JW, editors. William's obstetrics. $24^{\text {th }}$ ed. New York (NY): McGraw-Hill; 2014. Chapter 18p. 350-376.

[2]Simpson JL, Jauniaux ERM: Pregnancy loss. In: Gabbe SG, Niebyl JR, Simpson JL, eds. Obstetrics: Normal and Problem Pregnancies. 5th ed. Philadelphia, Pa: Elsevier Churchill Livingstone; chap 24, 2007 [3]Little AB. There's many a slip 'twixt implantation and the crib. N Engl J Med;2008; 319: 241-242.

[4]Wilcox AF, Weinberg CR, O'Connor JF, et al: Incidence of early loss of pregnancy. N Engl J Med 319:189, 1988

[5]Giacomucci E, Bulletti C, Polli V. Immunologically mediated abortion (IMA). J Steroid Biochem Mol Biol, 2008: 49: 107-121.

[6]Luise C, Jermy K, May C, et al: Outcome of expectant management of spontaneous first trimester miscarriage: observational study. BMJ 324:873, 2002

[7]Kollitz K, Meyn, Lohr P, Creinin M: Mifepristone and misoprostol for early pregnancy failure: a cohort analysis. Am J Obstet Gynecol 204:386.e1-6, 2011

[8]Neilson JP, Gyte GM, Hickey M, et al: Medical treatments for incomplete miscarriage (less than 24 weeks). Cochrane Database Syst Rev 1:CD007223, 2010

[9]Creinin MD, Huang X, Westhoff C: et al: Factors related to successful misoprostol treatment for early pregnancy failure. Obstet Gynecol 107:901, 2006 
Thi-Qar Medical Journal (TQMJ): Vol.(13), No.(1), 2017

\section{Email:utjmed@utq.edu.iq}

[10] Smith LF, Ewings PD, Guinlan $\mathrm{C}$ : Incidence of pregnancy after expectant, medical, or surgical management of spontaneous first trimester miscarriage: long term follow-up of miscarriage treatment (MIST) randomized controlled trial. BMJ 339:b3827, 2009

[11] Zhang J, Gilles J, Barnhart K, Creinin M, Westhoff C, Frederick M (2005): Drug Offers Alternative to Surgical Treatment After Miscarriage. New England Journal of Medicine.

[12] Henshaw R, Cooper K, elRefaey $\mathrm{H}$. Medical management of miscarriage: non-surgical uterine evacuation of incomplete and inevitable spontaneous abortion. $\mathrm{Br}$ Med J;2003; 306: 894-895.

[13] Hughes J, Ryan M, Hinshaw $\mathrm{K}$ et al. The costs of treating miscarriage: a comparison of medical and surgical management. Br J Obstet Gynaecol;2006: 103: 1217-1221.

[14] Taylor J, Diop A, Blum J, Dolo O, Winikoff B . Oral misoprostol as an alternative to surgical management for incomplete abortion. Int J Gynaecol obstet;2011: 112 (1): 40- 4.

[15] El-Bradie SM, Elsaid $\mathrm{MH}$, Ragab WS, Elssery KM, Mahmoud M. Endometrial thickness and serum beta$\mathrm{hCG}$ as predictors of the effectiveness of oral misoprostol in early pregnancy failure. J Obstet Gynaecol Can;2008: 30 (10): 877-81.

[16] Rausch M, Lorch S, Chung K, Frederick M, Zhang J, Barnhart K. A cost-effectiveness analysis of
Web Site: https://imed.utq.edu.iq

surgical versus medical management of early pregnancy loss. Fertil Steril. $2012 ; 97(2): 355-60$.

[17] World Health Organization (WHO) Unsafe abortion: Global and regional estimates of the incidence of unsafe abortion and associated mortality in 2008.6. Geneva: WHO; 2011.

[18] Nanda $K^{1}$, Peloggia

A, Grimes D, Lopez L, Nanda G. Expectant care versus surgical treatment for miscarriage. Cochrane Database Syst Rev. $2006 \mathrm{Apr}$ 19;(2):CD003518.

[19] Zhang J, Gilles JM, Barnhart K, Creinin MD, Westhoff C, Frederick MM; National Institute of Child Health Human Development (NICHD) Management of Early Pregnancy Failure Trial. A comparison of medical management with misoprostol and surgical management for early pregnancy failure. N Engl J Med. 2005 Aug 25;353(8):761-9.

[20] Behnamfar F, Mahdian M, Rahimi F, Samimi M. Misoprostol Abortion:

Ultrasonography versus Beta-hCG Testing for Verification of Effectiveness. Pak J Med Sci. 2013 Nov;29(6):1367-70.

[21] Neilson JP, Gyte GM, Hickey M, Vazquez JC, Dou L. Medical 226 treatments for incomplete miscarriage (less than 24 weeks). Cochrane Database Syst Rev. 2010(1):CD007223.

[22] Petersen SG, Perkins AR, Gibbons KS, Bertolone JI, Mahomed 
Thi-Qar Medical Journal (TQMJ): Vol.(13), No.(1), 2017

Email:utjmed@utq.edu.iq

K. The medical management of missed miscarriage: outcomes from a prospective, single-centre, Australian cohort. Med J Aust. 2013 Sep 2;199(5):341-6.

[23] Kovavisarach E, Jamnansiri C. Intravaginal misoprostol 600 microg and 800 microg for the treatment of early pregnancy failure. Int $\quad J \quad$ Gynaecol Obstet. 2005 Sep;90(3):208-12.

[24] Verschoor MA, Lemmers

M, Bossuyt PM, Graziosi

GC, Hajenius PJ, Hendriks DJ, van Hooff MA, van Meurs HS, Opmeer BC, van Tulder MW, Bouwma L,Catshoek R, Geomini P, Klinkert ER, Langenveld J, Nieboer TE, van der Ploeg JM, Radder CM, Spinder T, van der Voet LF, Mol BW, Huirne JA, Ankum WM. Surgical versus expectant management in women with an incomplete evacuation of the uterus after treatment with misoprostol for miscarriage: the MisoREST trial. BMC Pregnancy

Childbirth. 2013 May 2;13:102.

[25] Blandine T, Ouattara AZ, Coral A, Hassane C, Clotaire H, Dao B, Lankoande J, Diop A, Blum J. Sublingual [corrected] misoprostol as first-line care for incomplete abortion in Burkina Faso. Int J Gynaecol Obstet. 2012 Nov;119(2):166-9.

[26] Fawole $\mathrm{AO}^{1}$, Diop

A, Adeyanju AO, Aremu OT, Winikoff B. Misoprostol as firstline treatment for incomplete abortion at a secondary-

\section{Web Site: https://imed.utq.edu.iq}

level health facility in Nigeria. Int $\mathbf{J}$ Gynaecol

Obstet. 2012 Nov;119(2):170-3.

[27] Ngoc NT, Shochet T, Blum J, Hai PT, Dung DL, Nhan TT, Winikoff B. Results from a study using misoprostol for management of incomplete abortion in Vietnamese hospitals: implications for task shifting. BMC Pregnancy Childbirth. 2013 May 22;13:118.

[28] Hooker AB, Lemmers M, Thurkow AL, Heymans MW, Opmeer BC, Brölmann HA, Mol BW, Huirne JA. Systematic review and metaanalysis of intrauterine adhesions after miscarriage: prevalence, risk factors and long-term reproductive outcome. Hum Reprod Update. 2014 MarApr;20(2):262-78.

[29] Lemmers M, Verschoor

MA, Hooker AB, Opmeer

BC, Limpens J, Huirne JA, Ankum WM, Mol BW. Dilatation and curettage increases the risk of subsequent preterm birth: a systematic review and meta-analysis. Hum Reprod. 2016 Jan;31(1):34-45.

[30] Lemmers M, Verschoor MA, Oude Rengerink K, Naaktgeboren C, Opmeer BC, Bossuyt PM, Huirne JA, Janssen CA, Radder C, Klinkert ER, Langenveld J, Catshoek R, Van der Voet L, Siemens F, Geomini P, Van Hooff MH, Van der Ploeg JM, Coppus SF, Ankum WM, Mol BW. MisoREST study group. MisoREST: surgical versus expectant management in women with an incomplete 
Thi-Qar Medical Journal (TQMJ): Vol.(13), No.(1), 2017

Email:utjmed@utq.edu.iq

evacuation of the uterus after misoprostol treatment for miscarriage:

a randomized controlled trial. Hum
Web Site: $\underline{\text { https://imed.utq.edu.iq }}$

Reprod. 2016 Sep 2. [Epub ahead of print]

\section{مقارنة العلاج الاوائي مقابل العلاج الجراحي لعدم اكتمال الإجهاض في الفصل الاول}

\section{الخلاصة}

الهـف: هو تقييم فعالية وسلامة العلاج الطبي (الدوائي) للإجهاض غير مكتمل باستخدام الميسوبروستول مقارنة بالعمليات الجر احية.

طر ائق العمل: شملت دراسة مقارنة م ـ ب امر أة عانين من الإجهاض خلال الاشهر الثلاث الاولى من الحمل للفترة بين

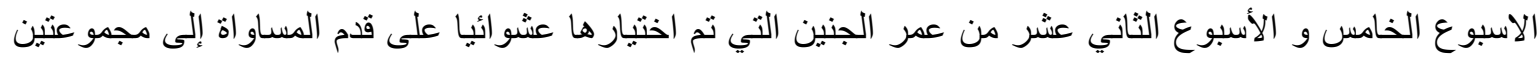

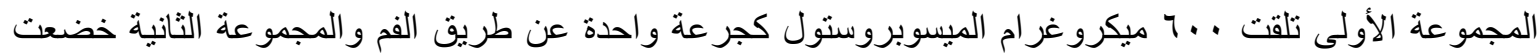
لتوسع العمليات الجر احية والإخلاء. وكانت النتيجة الأولية نجاح العلاج.

النتائج: لم تكن هناك فروق ذات دلالة إحصائية بين استخدام ميزوبروستول و و التداخل الجراحي فيما يتعلق سمك بطانة

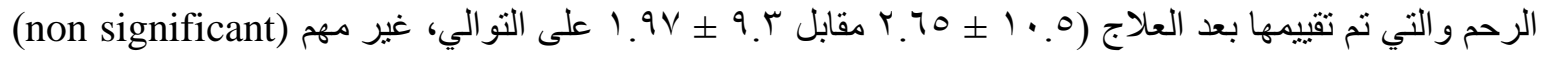

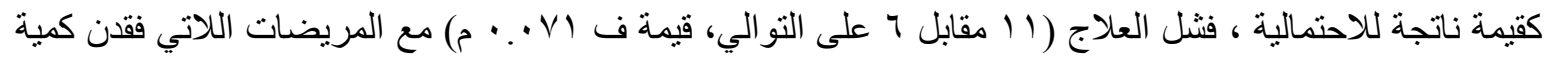

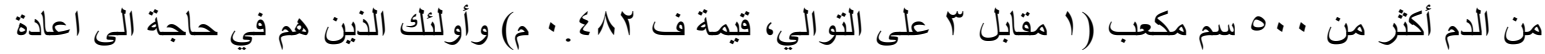





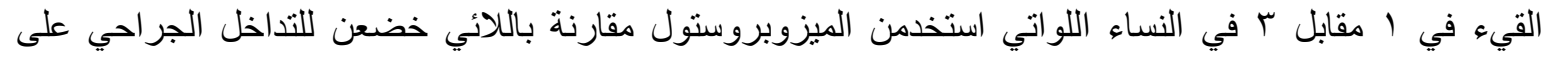

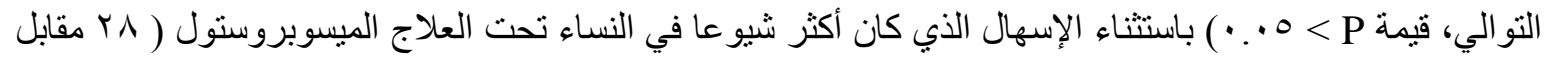

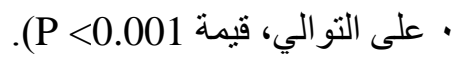

الاستنتاج: ثبت من خلال الدراسة ان العلاج الدوائي كان فعالا و مقبو لا و أقل تكلفة من التداخل الجراحي في النساء اللو اني يعانين من عدم اكتمال الحمل (الإجهاض). 